\title{
Major, Minor and Trace Elements Linum Usitatissimum in Libya
}

\author{
Amera Elfaki Edris ${ }^{1}$ and Ahmed Ali Mustafa ${ }^{2 *}$ \\ ${ }^{1}$ Deptartment of Chemistry, Tripoli University, Libya \\ ${ }^{2}$ Deptartment of Botany, Omdurman Islamic University, Sudan \\ *Corresponding author: Ahmed Ali Mustafa, Department of Botany, Faculty of Science and Technology, Omdurman Islamic University, \\ Omdurman, Sudan. \\ To Cite This Article: Ahmed Ali Mustafa, Major, Minor and Trace Elements Linum Usitatissimum in Libya. Am J Biomed Sci \& Res. 2019 - 6(3). \\ AJBSR.MS.ID.001033. DOI: 10.34297/AJBSR.2019.06.001033.
}

Received: 阱 November 14, 2019; Published: 眥 November 22, 2019

\begin{abstract}
In this study the plant Linum usitatissimum Linn. which belong to linaceae family, it is one of the most ancient crops cultivated in Egypt. It is also cultivated in Libya as an oil seed plant. The results shown high the concentration in $\mathrm{K}(9422 \pm 1.01)$, Ca (4621 \pm 4.73 ), Na (1901 \pm 0.58$)$, $\mathrm{Mn}$ (25.59 \pm 3.38$), \mathrm{Cu}(16.93 \pm 3.48)$, in $\mathrm{HNO}+\mathrm{HClO}$. Ni (7.96 \pm 7.29$), \mathrm{Pb}(21.41 \pm 4.76)$ in $\mathrm{HNO}_{3}+\mathrm{H}_{2} \mathrm{O}_{2}$. And $\mathrm{Mg}(3471 \pm 3.36), \mathrm{Zn}(36.24 \pm 2.38)$, $\mathrm{Li}$ $(11.43 \pm 0.50)$ in dry ashing. While Not detection in $\mathrm{Cr}, \mathrm{Co}, \mathrm{Cd}$. The results obtained shown that was a Linum usitatissimum., a good source of food and therapeutic agents which could be of use food and pharmaceutical industries, information about the chemical composition of the oil could then be useful in the classification of this plant.
\end{abstract}

Keywords: Linum usitatissimum; Minor; Trace elements; Libya

\section{Introduction}

Plants used in traditional medicine contain a wide range of ingredients that can be used to treat chronic as well as infectious diseases. The medicinal value of plants lies in some chemical substances that produce a define physiological action on human body. The use of medicinal plants as traditional medicines is well known in rural areas of many developing countries [1]. The long history of clinical application and natural origin guarantee that herbal products are mostly effective and nontoxic [2]. In recent years, considerable research has been done on an array of plants having medicinal values. Katan is a famous Unani drug used in a number of pathological conditions. Although entire plant has medicinal value, but its seed and oil are more important and have broad medicinal values.

Katan is an annual herb of about $0.7 \mathrm{~m}$ high with blue flowers and a globular capsule. The seed are ovate, flattened and obliquely pointed at one end, about $4-6 \mathrm{~mm}$ long and $2-2.5 \mathrm{~mm}$ broad. The taste is brown, glossy and finely pitted odorless, taste mucilaginous and oily. If cruciferous seed are present, a pungent odour and taste may develop on crushing and moistening [3]. Seeds are sown at the end of March and flower in June. Stems are solitary or few corymbose branched, branches ascend towards the apex. Flowers are of about
$2.5 \mathrm{~cm}$ across in corymbose, panicles, sepals are 5 . Linseed stands fourth after mustard, sesame and groundnut in edible oil production of the world [4]. Knowledge of the composition and requirements of the body has been apparent that not only proteins, fats and carbohydrates, but also minerals and water are essential to life. Based on the arbitrary division we will consider the elements that present in the investigated samples in concentration range from $1 \%$ to $100 \%$ as major elements of the sample. If the concentration range is from 0.01 to $1.0 \%$, then element is considered as minor element constituent of sample. [5].

The following elements have been approved to be essential for the well-being of the human body; these elements are (C, H, O, N, S, $\mathrm{Cl}, \mathrm{P}, \mathrm{Ca}, \mathrm{Mg}, \mathrm{Na}, \mathrm{K}, \mathrm{Fe}, \mathrm{Si}, \mathrm{Mn}, \mathrm{Zn}, \mathrm{Fe}, \mathrm{Cu}, \mathrm{Co}, \mathrm{Cr}, \mathrm{Se}, \mathrm{V}, \mathrm{Mi}, \mathrm{F}, \mathrm{Sn}$, and possibly $\mathrm{Ni}$. We can divide these essential elements depending on their daily human body requirements into two classes one macro elements (macronutrients) in this group are included the elements of which our daily requirements is more than $100 \mathrm{mg} / \mathrm{g}$, these are (Ca, P, Na, Cl, Mg, Fe and S). Two trace elements (micronutrients) the daily requirements of minerals in this group range from less than $1 \mathrm{mg} / \mathrm{g}$ and up to $100 \mathrm{mg} / \mathrm{g}$, this group includes (Cu, Zn, Mn, I, Mo, Se, f, Cr, Co, and Si). 


\section{Material and Methods}

\section{Plant collection}

The plant Linum usitatissimum L. Leaves was collected in the April 2016 from Tripoli city in Libya and different area around it by rooting the plants off, and identified by Botany Dept.F.S of Elfateh University, after that the plants left to dry for a period of 5 days, after dried plant samples were the homogenized in pistil and mortar (Images 1-3).
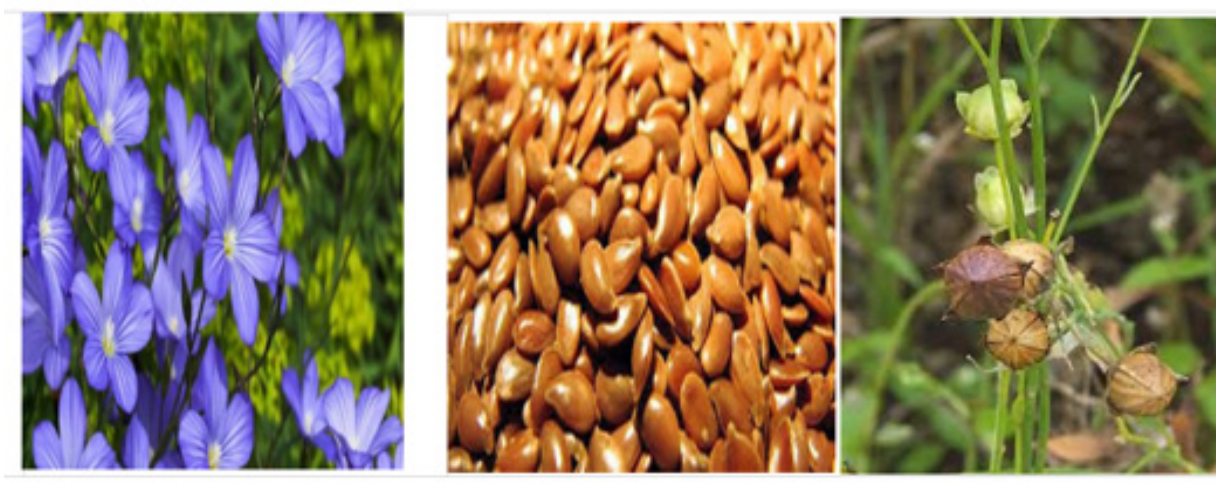

Photo 1: Linum usitatissimum L. plant. Photo 2: Linum usitatissimum L. flower. Photo 3: Linum usitatissimum L. seed.

\section{Experiment}

Practically four methods were used; the dry ashing, wet digestion, Aqueous Extraction and as tea by detection of leaves in boiling water:

Dry ashing: Practically the plant material was washed with deionized water, and the sample placed in open dishes then put into a $90^{\circ} \mathrm{C}$ oven for $24 \mathrm{hrs}$ minimum. Then taken out from the oven and allow to cool in desiccators. Cleaning the silica crucibles by dipping in $(1+1)$ nitric acid and heating to boiling point. Then crucibles were transferred to a muffle furnace and burned at $500^{\circ} \mathrm{C}$. When crucibles cooled down $2 \mathrm{gm}$ from each different plant sample were specified and put into each crucible. Then after crucibles were placed into a muffle furnace again, slowly increasing the temperature up to $500^{\circ} \mathrm{C}$ and maintain for 8hrs then remove out and allow cooling.

Ash was dumped by a few drops of distilled water and $1 \mathrm{ml}$ of $(1+1)$ suprapur; $65 \%$ nitric acid added in drop-wise. Crucibles are taken to a water bath after contents dried, and again placed into the muffle furnace for $2 \mathrm{hrs}$ at $500^{\circ} \mathrm{C}$ further then after allow cooling. Solutions are prepared by dissolving the contents of each one crucible into $4 \mathrm{ml}(1+1)$ warm suprapur nitric acid. Poured into $50 \mathrm{ml}$ volumetric flasks grade A. Finally, the full volume of $50 \mathrm{ml}$ flask is reached by adding $0.1 \mathrm{M}$ of $\mathrm{HNO}_{3}$ in each [6].

Wet Digestion: Practically the plant material was washed with deionized water, and the sample placed in open dishes then into a $90^{\circ} \mathrm{C}$ oven for $24 \mathrm{hrs}$ minimum. Then taken out from the oven and allow to cool in desiccators. Beakers are cleaned by soaking into $(1+1)$ suprapur; $65 \%$ nitric acid, rinsed up by deionized water and placed into lab oven to dry. When beakers were cooled down 2gm were specified from each different plant sample and put into each a $80-\mathrm{ml}$ beaker, then add $20 \mathrm{ml}$ concentrated $\mathrm{HNO}_{3}$ to each specified sample, the beakers were covered with watch glasses as condenser. To aid digestion process the mixture was heated to reflux on an electric hot plate for $6 \mathrm{hrs}$, when cooled down then $6 \mathrm{ml}$ of concentrated $\mathrm{HClO}_{4}$ (assay $>60.00 \%$ ) were added and the mixture heated again at until fume released from the $\mathrm{HCLO}_{4}$ which was sucked up by fume hood, and clear solution obtained. To prepare the solutions the cool mixture was dissolved in $0.1 \mathrm{M} \mathrm{HNO}_{3}$ then filtered through a glass filter into $50 \mathrm{ml}$ volumetric flasks grad-A. Finally the full volume of $50 \mathrm{ml}$ flask is reached by adding $0.1 \mathrm{M}$ of $\mathrm{HNO}_{3}$ in each. The wet digestion with $30 \% \mathrm{H}_{2} \mathrm{O}_{2}$ : The same process in the previous experiment was conducted but adding $10 \mathrm{ml}$ of concentrated $30 \% \mathrm{H}_{2} \mathrm{O}_{2}$ as oxidizing agent into the sample content, noting that round flasks reflux system were used instead of beakers [6].

Aqueous extraction: Practically the plant material was washed with deionized water, and the sample placed in open dishes then into a $90^{\circ} \mathrm{C}$ oven for $24 \mathrm{hrs}$ minimum. Then taken out from the oven and allow to cool in desiccators. Then $2 \mathrm{gm}$ from each different plant sample were specified and put into clean $80-\mathrm{ml}$ beaker and $80 \mathrm{ml}$ of deionized water was added to the beaker and covered with a watch glass. Then the mixture was heated to reflux for 60 minutes. To prepare the solutions the cool mixture was filtered through what man 42 paper into volumetric flasks grade-A. Finally the full volume of $50 \mathrm{ml}$ flask was reached by adding $0.1 \mathrm{M}$ of $\mathrm{HNO}_{3}$ in each [7].

Preparation of standard solution: Standard solution were prepared for each element from the standard salts of these elements, Working standard solutions of $\mathrm{Ca}, \mathrm{K}, \mathrm{Mg}$, $\mathrm{Na}, \mathrm{Fe}, \mathrm{Mn}, \mathrm{Zn}$, $\mathrm{Li}, \mathrm{Cu}, \mathrm{Cd}, \mathrm{Co}, \mathrm{Ni}, \mathrm{Pb}$, and $\mathrm{Cr}$ were prepared from stock standard solution $1000 \mathrm{ppm}$ in $2 \mathrm{~N} \mathrm{HNO}_{3}$ the water used in all preparations was deionized water obtained from Tripoli west power station. and calibration curves were drawn for each element. Refluxing $2.00 \mathrm{~g}$ samples of the plant tissues for about one hours then the water extracts were analyzed for their elemental contents. 


\section{Results and Discussion}

From the results in Table 1 we can conclude that the concentration of potassium is higher than the concentration of calcium, the concentration of calcium is higher than the concentration of sodium, the concentration of magnesium is higher than the concentration of sodium, and the concentration of sodium is higher than the concentration of iron as the follow order:

$$
\mathrm{K}>\mathrm{Ca}>\mathrm{Mg}>\mathrm{Na}>\mathrm{Fe}
$$

The concentration of macronutrients potassium, sodium calcium, magnesium and iron in this Libyan wild medicinal plant Linum usitatissimum L. was found within the concentrations ranges of others medicinal plants analyzed in some other countries Serbia, Nigeria, Brazil, Yugoslavia, Pakistan [8-10]. from the results which were found to have following average solution concentrations for potassium, sodium, calcium, magnesium and iron $[(7760 \mu \mathrm{g} / \mathrm{g})$,

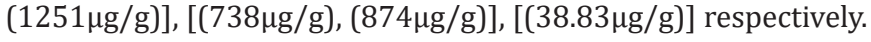

However even extraction of smaller amounts of this easily available plant still could contribute significantly to satisfy the RDA of this macronutrients. From the data in Table 1 and Figures 1-3 we can conclude that the Libyan wild medicinal plant Linum usitatissimum L. has a significant amount of macronutrients potassium, sodium, calcium, magnesium and iron.

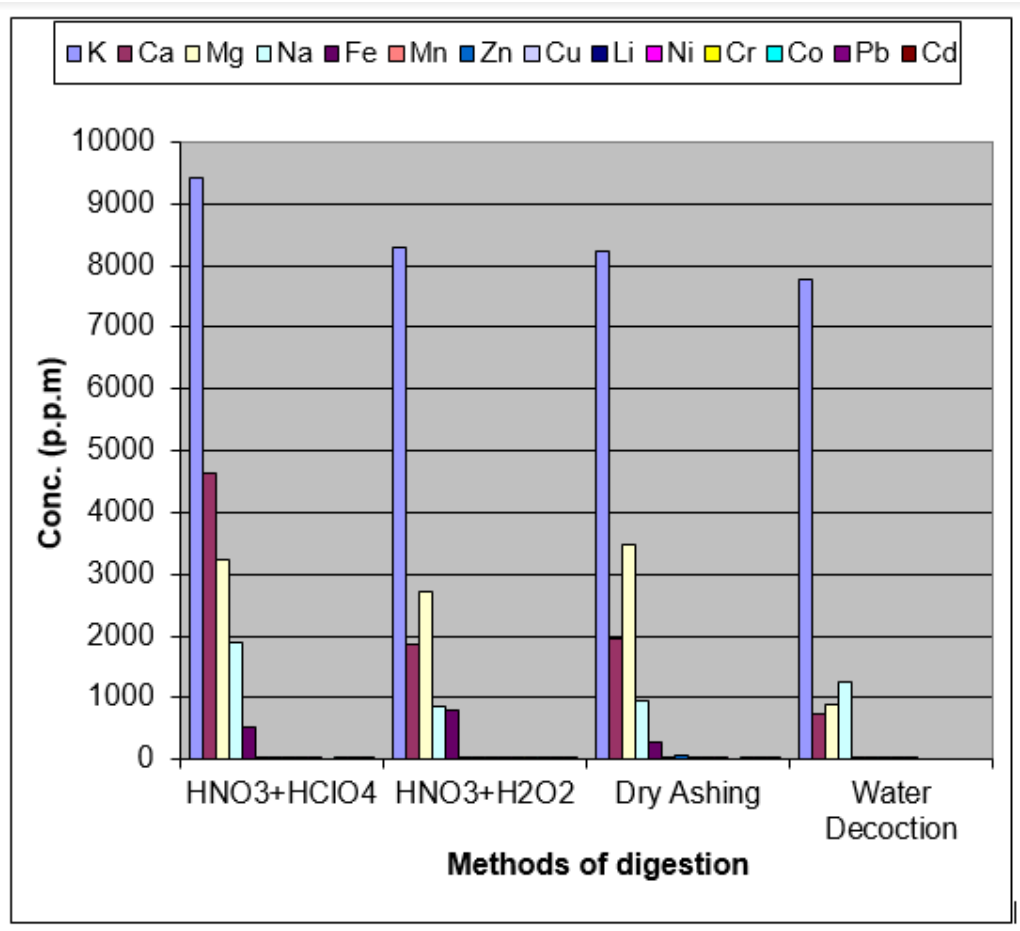

Figure 1: The contents $(\mu \mathrm{g} / \mathrm{g})$ of elements in Linum usitatissimum L. using four methods of digestion.

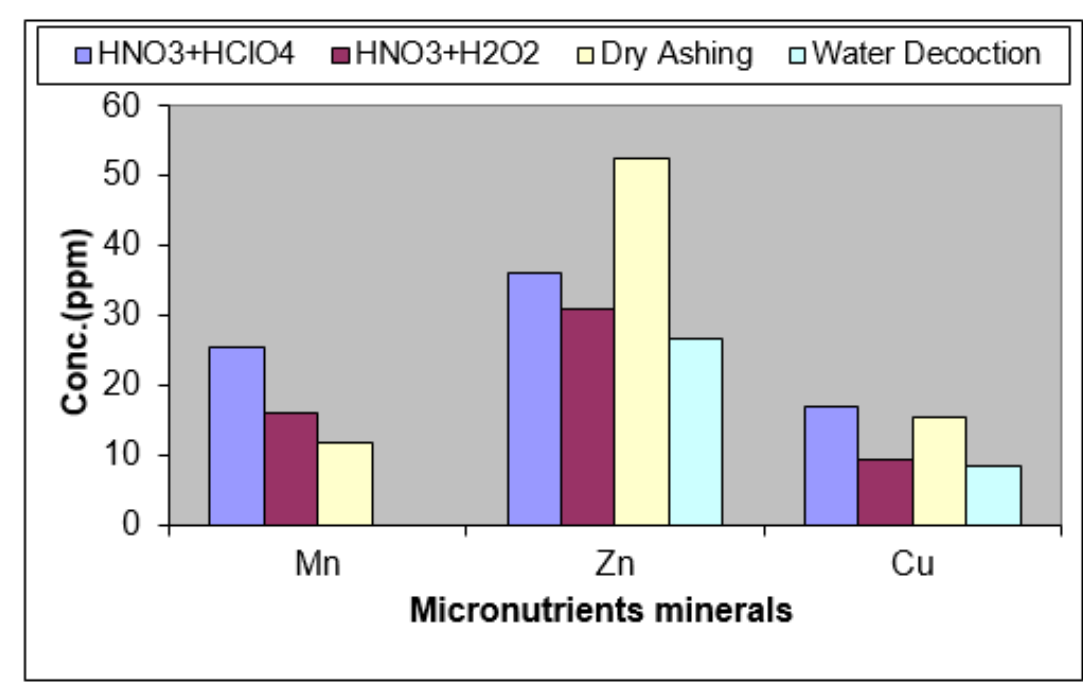

Figure 2: The contents $(\mu \mathrm{g} / \mathrm{g})$ of micro-nutrients, $(\mathrm{Mn}, \mathrm{Zn}$, and $\mathrm{Cu})$. 


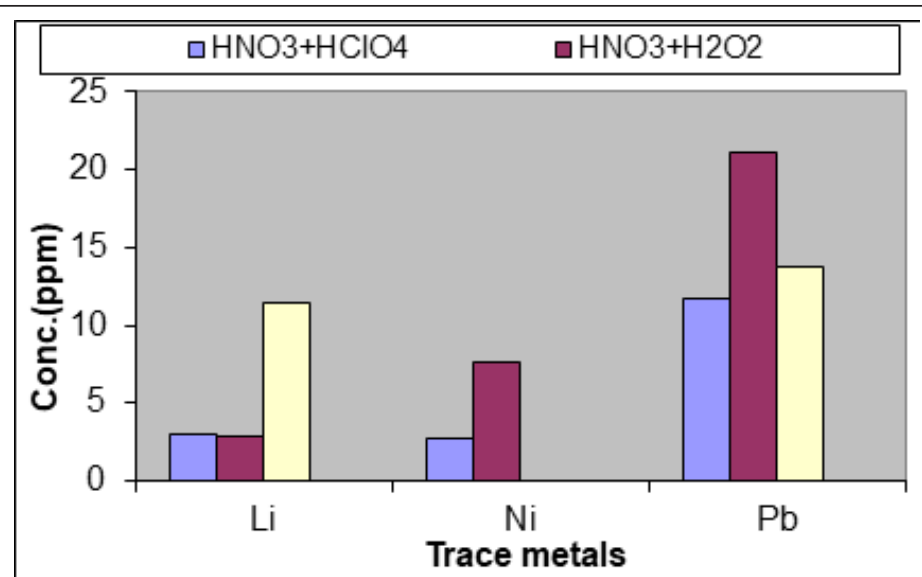

Figure 3: The contents $(\mu \mathrm{g} / \mathrm{g})$ of trace elements $(\mathrm{Li}, \mathrm{Ni}$, and $\mathrm{Pb})$.

\section{Concentration values of elements}

The concentration values of the 14 elements were represented in the following graphs:

Dry ashing procedure to destroy the organic matrix resulted in mean concentration $(11.34 \mu \mathrm{g} / \mathrm{g})$ for lithium. From the result, we can observed that the concentration of copper and lithium based on dry ashing method gave a higher amount than other method of digestion. The presence of the trace metal manganese copper, nickel, lithium, were undetected in the water extract under our experimental conditions and no further attempts were made to concentrate the samples by evaporation and then measuring these trace elements because of the difficulty of the access to A.A.S instrument. The concentration of zinc, manganese, nickel, and copper in this Libyan wild medicinal plant was found within the concentrations ranges of others medicinal plants analyzed in some other countries (Serbia, Jordan, Brazil, Spain, Nigeria, Egypt, and South Africa) [11-13]. The relative order of micro-nutrients manganese, copper, zinc, chromium, nickel and lithium in this plant were found as follow:

$$
\mathrm{Zn}>\mathrm{Mn}>\mathrm{Li} \sim \mathrm{Cu}>\mathrm{Ni}
$$

\section{Concentration of the toxic trace elements}

The concentration of the toxic trace element lead was found to range from $(11.67 \mu \mathrm{g} / \mathrm{g}$ to $21.41 \mu \mathrm{g} / \mathrm{g})$ by using two procedures of digestion and dry ashing method. The concentration of lead in studied medicinal plant was found to be in agreement with the finding in Yugoslavia, Jordan, and Brazil [14]. The contents of metal lead in studied medicinal plant samples were not detected by refluxing the plant tissues in water for about 1 hour. Concentration of cobalt chromium and cadmium were not detected in all samples of studied plan by all procedures used in this study possibly indicating the very low or the absence of such elements in studied plant. It is remarkable that the metal determination in plant tissue revealed that potassium metal has the highest concentration of all other studied elements in this plant while the lowest detectable concentration under the conditions of our work was that of nickel. The differences in the concentration of the elements attributed to soil composition and the climate in which the plant grows.

Generally in Linum usitatissimum L. were found the concentration of these elements potassium, sodium, calcium, magnesium and iron at minor levels, manganese, copper, zinc, chromium, nickel lithium and lead at trace levels. The above results were presented in Table 1. The concentration of micronutrients manganese and Zinc as indicated in Table 1 were found at considerable values of concentration. based on digestion with a mixture of $\mathrm{HNO}_{3} / \mathrm{HClO}_{4}$ acids, a mixture of $\mathrm{HNO}_{3} / \mathrm{H}_{2} \mathrm{O}_{2}$ acids to extract the minerals and dry tissue samples, these results in agreement with CE Dunn [11]. By water extract procedure, the contents of Zinc were found to be $(25.20 \mu \mathrm{g} / \mathrm{g})$. The concentration of micronutrients copper and nickel as indicated in Table 1 were found at trace amount of concentration based on dry tissue samples and digestion with a mixture of $\mathrm{HNO}_{3} /$ $\mathrm{HClO}_{4}$ acids.

\begin{tabular}{|c|c|c|c|c|}
\hline Element & $\mathrm{HNO}_{3}+\mathrm{HClO}_{4}$ & $\mathrm{HNO}_{3}+\mathrm{H}_{2} \mathrm{O}_{2}$ & Dry Ashing & Water Decoction \\
\hline K & $\begin{array}{c}9422 \pm 1.01 \\
(9280-9469)\end{array}$ & $\begin{array}{c}8284 \pm 1.32 \\
(8137-8396)\end{array}$ & $\begin{array}{c}8238 \pm 1.82 \\
(8080-8396)\end{array}$ & $\begin{array}{c}7760 \pm 0.12 \\
(7739-7771)\end{array}$ \\
\hline $\mathrm{Ca}$ & $\begin{array}{c}4621 \pm 4.73 \\
(4432-4811)\end{array}$ & $\begin{array}{c}1875 \pm 10.08 \\
(1780-2159)\end{array}$ & $\begin{array}{c}1951 \pm 10.08 \\
(1780-2121)\end{array}$ & $\begin{array}{l}738 \pm 25.58 \\
(643-1022)\end{array}$ \\
\hline $\mathrm{Mg}$ & $\begin{array}{c}3228 \pm 0.16 \\
(3221-3232)\end{array}$ & $\begin{array}{c}2718 \pm 0.414 \\
(2705-2731)\end{array}$ & $\begin{array}{c}3471 \pm 3.36 \\
(3314-3595)\end{array}$ & $\begin{array}{l}874 \pm 1.90 \\
(853-891)\end{array}$ \\
\hline $\mathrm{Na}$ & $\begin{array}{c}1901 \pm 0.58 \\
(1887-1912)\end{array}$ & $\begin{array}{l}863 \pm 3.78 \\
(847-912)\end{array}$ & $\begin{array}{c}945 \pm 3.99 \\
(912-978)\end{array}$ & $\begin{array}{c}1251 \pm 2.00 \\
(1216-1275)\end{array}$ \\
\hline
\end{tabular}




\begin{tabular}{|c|c|c|c|c|}
\hline $\mathrm{Fe}$ & $\begin{array}{c}534 \pm 3.91 \\
(517-561) \\
\end{array}$ & $\begin{array}{l}791 \pm 2.33 \\
(768-814) \\
\end{array}$ & $\begin{array}{l}281 \pm 9.79 \\
(254-320) \\
\end{array}$ & $\begin{array}{c}38.83 \pm 3.29 \\
(37.72-39.93) \\
\end{array}$ \\
\hline $\mathrm{Mn}$ & $\begin{array}{c}25.59 \pm 3.38 \\
(24.85-26.35)\end{array}$ & $\begin{array}{c}16.13 \pm 8.99 \\
(15.40-18.31)\end{array}$ & $\begin{array}{c}11.75 \pm 6.36 \\
(11.37-12.87)\end{array}$ & ND \\
\hline $\mathrm{Zn}$ & $\begin{array}{c}36.24 \pm 2.38 \\
(34.12-36.99) \\
\end{array}$ & $\begin{array}{c}31.09 \pm 2.03 \\
(30.40-30.98)\end{array}$ & $\begin{array}{c}52.43 \pm 9.15 \\
(48.54-56.57) \\
\end{array}$ & $\begin{array}{c}25.20 \pm 2.58 \\
(24.95-25.95) \\
\end{array}$ \\
\hline $\mathrm{Cu}$ & $\begin{array}{c}16.93 \pm 3.48 \\
(16.42-17.45)\end{array}$ & $\begin{array}{c}9.31 \pm 0.64 \\
(9.21-9.36)\end{array}$ & $\begin{array}{c}15.40 \pm 5.41 \\
(14.38-16.42) \\
\end{array}$ & $\begin{array}{c}8.36 \pm 8.73 \\
(7.27-8.72) \\
\end{array}$ \\
\hline $\mathrm{Li}$ & $\begin{array}{l}2.94 \pm 0.476 \\
(2.91-3.01)\end{array}$ & $\begin{array}{c}2.89 \pm 2.76 \\
(2.77-2.99) \\
\end{array}$ & $\begin{array}{c}11.43 \pm 0.50 \\
(11.37-11.50)\end{array}$ & ND \\
\hline $\mathrm{Ni}$ & $\begin{array}{l}2.65 \pm 22.18 \\
(1.77-2.95) \\
\end{array}$ & $\begin{array}{c}7.96 \pm 7.29 \\
(7.66-8.84) \\
\end{array}$ & ND & ND \\
\hline $\mathrm{Cr}$ & ND & ND & ND & ND \\
\hline Co & ND & ND & ND & ND \\
\hline $\mathrm{Pb}$ & $\begin{array}{c}11.67 \pm 10.02 \\
(11.08-13.44)\end{array}$ & $\begin{array}{c}21.41 \pm 4.76 \\
(20.52-22.88)\end{array}$ & $\begin{array}{c}13.79 \pm 9.17 \\
(11.08-13.44)\end{array}$ & ND \\
\hline $\mathrm{Cd}$ & ND & ND & ND & ND \\
\hline
\end{tabular}

Note: Means $\pm R S D \%$, (Mean conc. Range), ND: Not detection.

However, using a mixture of $\mathrm{HNO}_{3} / \mathrm{H}_{2} \mathrm{O}_{2}$ acids to extract these minerals gave inferior values of concentration for copper and nickel respectively. Dry ashing procedure to destroy the organic matrix resulted in mean concentration $(15.40 \mu \mathrm{g} / \mathrm{g})$ for copper and not detected for nickel. The concentration of lithium result in very small concentration) based on dry tissue samples and digestion with a mixture of $\mathrm{HNO}_{3} / \mathrm{HClO}_{4}$ acids and $\mathrm{HNO}_{3} / \mathrm{H}_{2} \mathrm{O}_{2}$ acids to extract the minerals.

\section{Conclusion}

For this reason, further detailed clinical research appears worth wile to explore the full therapeutic potential of this drug in order to establish it as a standard drug.

\section{References}

1. Bharathajothi P, Bhaaskaran CT (2014) Phytochemical and pharmacological evaluations of Aristolochia bracteolata Lam. Asian J Plant Sci Res 4(6): 15-19.

2. Shin JY, Park HJ, Kwon M, Son CG (2010) Scientific evaluation of the chronic toxicity of the herbal medicine CGX in beagle dogs. Food Chem Toxicol 48(2): 743-749.

3. Evans WC, Trease, Evans (2009) Pharmacognosy, (16 ${ }^{\text {th }}$ edn) Saunders Elsevier Edinburgh London New York Philadelphia St Louis Sydney Toronto p: 88.

4. Desta Mekebo, Bhagwan Singh Chandravanshi (2014) Levels of Essential and non Essential metals in Linsed (Linum usitatissimum) cultivated in Ethiopia. Bull Chem Soc Ethiop 28(3): 349-362.
5. Ali SI, SMH Jafri 1976-1977. Flora of Libya. Nos 1-24 University of Alfateh. Tripoli-Libya.

6. RH Scott, A Strashim (1975) Analytical Chimica Acta 76: 71-78.

7. http//:sehha.com/nutrition/minerals/minerals.htm.

8. Anwar Ali Shad, Hamidullah shah, FK Khattak, , Nabeela G Dar, Jehan Bakht (2002) Proximate and Mineral Constituents of Medicinal Herb Fagonia Arabica. Asian Journal of Plant Sciences 1(6): 710-711.

9. Shaito SR, TG Kazi (2001) Trace elements in two varieties of indigenous medicinal plants (Vinca rosea). Journal of Medical Sciences (Faisalabad) 1(2): 74-77.

10. HCC Maduka, ZSC Okoye (2002) Elemental composition of Sacoglottis gabonensis a Nigerian alcohol beverage addition. Pakistan journal of biological sciences 5(1): 66-68.

11. CE Dunn, RR Brooks, J Edmondson, M Leblanc, R d reeves (1996) Biologeochemical studies of meta-tolerant plant from solution. Morocco Journal of geochemical Exploration 56(13-22).

12. Tazi L, Zeiger E (1998) Mineral nutrition in plant physiology, ( $\left.2^{\text {nd }} e d n\right)$, Sinauer Associates Inc Sunder, MA, pp. 9103-9124.

13. Maria Mozarin Beserra Almeida, Maria de Fatima Gomes Lopes (2005) Determination of minerals in medicinal plants. Print Issu 0101-2061.

14. Salameh Amr, Sinisa Dordevice (2000) The investigation of the quality of Salvia. Officinalis L. Origination from Jordan. The scientific journal 1(5): 103-108. 